\title{
IMPACT OF GHG EMISSION FROM PALM OIL MILL EFFLUENTS AND POPULATION GROWTH, GDP PER CAPITA CHANGE, AND THE TECHNOLOGY
}

\author{
By: \\ Erwinsyah $^{1}$ \\ Tjipto Djuhartono ${ }^{2}$ \\ Indraprasta University of PGRI - Jakarta \\ erwinsyah.unindra@gmail.com; tjiptodjuhartono@gmail.com
}

\begin{abstract}
The palm oil sector gives a significant contribution to the Indonesian economy and reached 34.5 million tons or 58 percent of world production in the year 2016. The scientific community agrees that palm oil expansion can contribute to the emission of Green House Gasses, including methane emissions from palm oil mill effluent (POME). The purpose of this research is to develop a model for assessing environmental impacts caused by the production of methane from POME. This study hypothesizes a correlation between the increasing population and changes in their GDP per capita of main palm oil importing countries with changes in Regional GDP in the provinces of Riau, North Sumatra, Central Kalimantan, South Sumatra, and West Kalimantan. The econometric analyses used in this study performed with the Eviews Statistical Data Processing model. Data used for this study was from the year 2010 to the year 2016, taken from the official Indonesian statistics and palm oil statistics. The results of this research include the Indonesian oil palm production for the period 2010-2016, the oil palm and POME production in five provinces mentioned above, forecast Model of POME Production, POME production elasticity, and possible policy intervention on GHG methane emission reduction.
\end{abstract}

Keywords: GDP, GDP per capita, palm oil, POME, population, predicted POME production model

\section{A. INTRODUCTION}

Indonesia is the leading palm oil producer country in the world, and in 2016 it produced 34.5 million tons or equal to 58 percent of total palm oil production worldwide, followed by Malaysia (29 percent), Thailand (4 percent), and Colombia ( 2 percent). The remaining production was made by Nigeria, Ecuador, Honduras, Papua New Guinea, Ghana, and Guatemala (Varga, 2017). Indonesian palm oil production in 2016 increased to 34.5 million tons from the previous year's 31 million tons. Palm oil gives a very significant contribution to the Indonesian economy. Exports alone, in 2016, accounted for about 18.6 billion USD (Anon, 2017).

The palm oil planted area in Indonesia is expected to expand to respond to the current and future demand for this commodity. However, according to the Food and Agriculture 
Organization of the United Nations (FAO, 2014), in Indonesia there exists a wide yield gap, especially between smallholders and large private estate companies, that can be filled without the expansion of the planted area, but through the large-scale adoption of best management practices and replanting campaigns.

The purpose of this research paper is to find out how the population, GDP per capita, and technology can contribute to the production of POME and what interventions can be made to minimize the emission of GHG from POME.

\section{B. LITERATURE REVIEW}

According to Lacrosse as quoted in Nur (2014:15), beside the main product of oil palm, 1 ton of Fresh Fruit Bunches (FFB) produces some $600-700 \mathrm{~kg}$ of wastewater in the form of POME; $190 \mathrm{~kg}$ of fibers, palm kernel shells, and Empty Fruit Bunches (EFB); and 150-200 kg of crude palm oil, depending upon the variety and oil extraction rate (OER).

Several studies argue that oil palm expansion contributes to the production of Green House Gasses (GHG) emission due to land-use changes, and according to FAO (2014), the second-largest contributor to GHG emissions in the palm oil industry is the methane emitted from POME.

Kuala Lumpur Kepong Berhad (2016) reported that Almost 70 percent of the FFB ends up as biomass after being processed. It comes in the form of empty fruit bunches, fibers, and shells, as well as effluent. When anaerobic fermentation of POME takes place in an uncontrolled, unsealed infrastructure (e.g. open lagoon), $\mathrm{CH}_{4}$ is released directly into the atmosphere. The global warming potential of methane varies according to IPCC depending upon the time horizon considered. In general, the time horizon considered is 100 years and in this case, the latest emission factors from IPCC report 25 times the GWP of CO2. Ohimain and Izah (2014:1) state that methane and carbon dioxide emissions from POME contributing to global climate change could be avoided through the capture of the gases emitted by the POME in the form of biogas. Biogas biomethane (the result of upgrading of biogas) can be utilized as an energy source for heating, cooking and electricity generation. Besides, through the process of controlled anaerobic fermentation in biogas digesters, palm oil mills can recover most of the nutrients and organic carbon from the POME to minimize the quantity being discharged into the environment and can use the digestate (material remaining after anaerobic digestion) and the sludges from the POME as organic fertilizers and for storing carbon into the soils. The aforementioned increased palm oil production expected will lead to higher potential methane production from the palm oil processing industries, and a long history of the prospecting palm oil production will produce additional emission in future years.

According to the Ministry of Agriculture (2017), the total oil palm planted area and palm oil production in Indonesia increased steadily from 2010 to 2016 . A total planted area in 2015 was 11.2 million hectares, which increased to 11.9 million hectares in 2016 while palm oil production of 31 million tons in 2015, increased to 33.2 million tons in 2016. Most of the production was originated in the main oil palm plantations in North Sumatera, Riau, South Sumatra, West Kalimantan, and Central Kalimantan (Figure 1). 


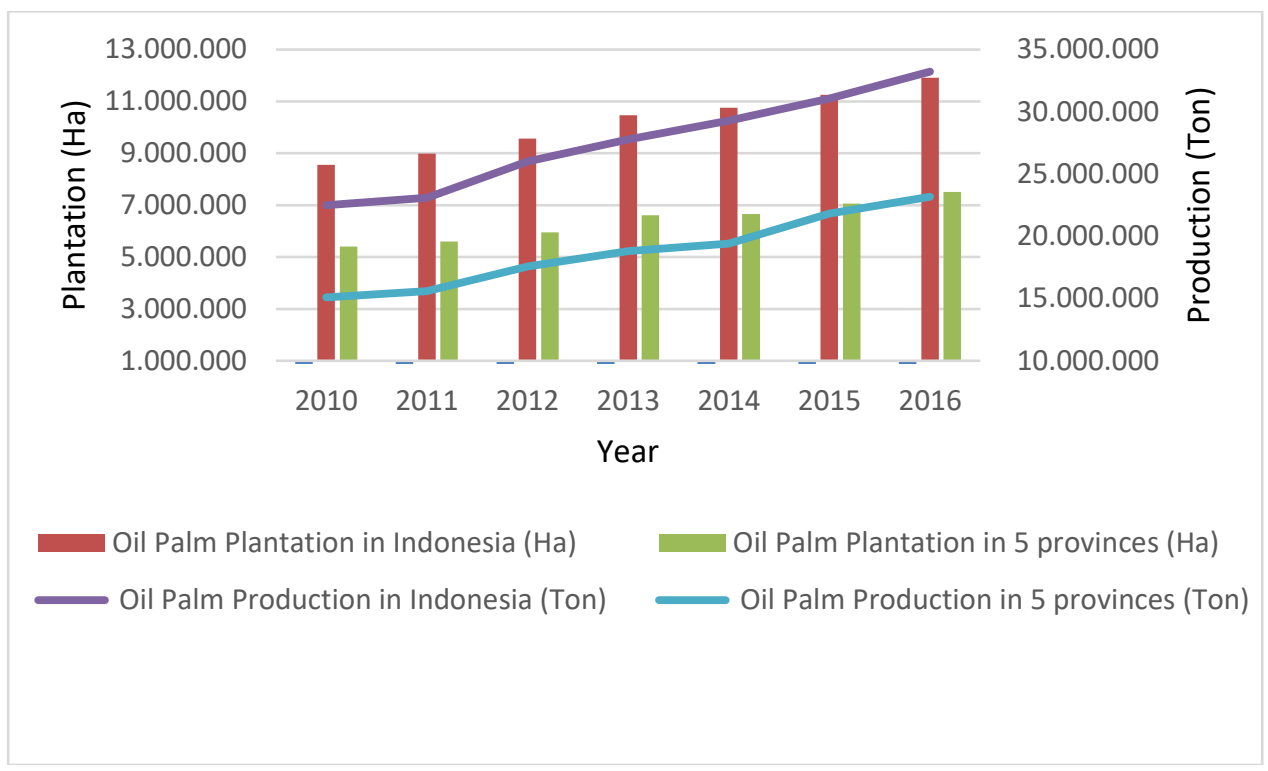

Figure 1. Oil Palm Plantation Area And Its Production, The Year 2010-2016 (Source: Statistics Indonesia 2011, Ministry of Agriculture (2016b and 2017)

The Indonesian oil palm plantations are managed by three major farming groups: smallholder farmers; state-owned companies (public); and privately-owned companies. In 2015, the production was dominated by privately-owned companies with about 59 percent of total CPO output (or 53 percent of the total planted area), followed by smallholders and state-owned companies with 34 percent (or 40 percent of the planted area), and 7 percent (or 7 percent of the planted area) respectively (Ministry of Agriculture, 2016a).

The major destination countries for the Indonesia palm oil export in the year 2016 were India, China, Pakistan, Netherlands, Spain, USA, Egypt, Bangladesh, Italy and Singapore, where the main highest destination exports were India (23 percent) followed by China (13 percent), and Pakistan (9 percent) (Figure 2).

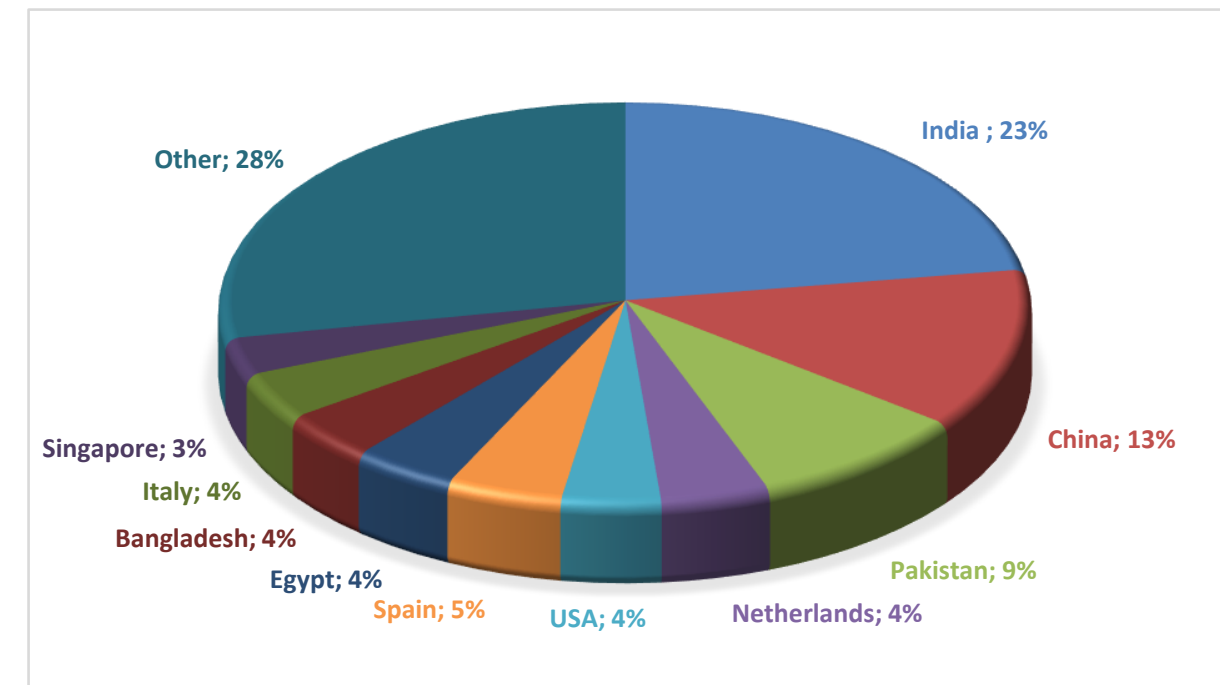

Figure 2. Export Destination Countries For The Indonesian Palm Oil In The Year 2016 (Source: Ministry of Agriculture, 2017) 
According to Pangsapa (2014), development could contribute to environmental degradation, and risks for human livelihoods. The development does not only contribute to economic growth but also a negative externality suffered by a third party as a consequence of the development. Tietenberg and Lewis (2012:564-588) mention that historically, population growth has also been held up as a major source of environmental degradation. With the increase in the size of the population drives up the demand for resources to meet the needs of the citizens, which in turn leads to impacts and environmental damages. In developing countries, steady growing birth rates and declining mortality rates will result in increased population growth rates. Miller (1999) stated that environmental problems, in general, are unpredictable, so environmental management mainly has to solve the complexity of problems and their impact.

According to Dornbusch, Fischer, and Startz (2011:11), The growth rate of the economy is the rate at which the gross domestic product (GDP) is increasing. Jones and Klenow (2016) state that welfare is strongly related to GDP per capita as an indicator of welfare used in most countries. Panayotou (2003:45-72) mentions that according to the Inverted-U relationship between environmental degradation and economic growth, known as "Environment Kuznets Curve", where agriculture and resource extraction intensify and industrialization takes off, both resource depletion and waste generation accelerate. At higher levels of development, structural changes towards information-based industries and services, more efficient technologies, and increased demand for environmental conservation result in leveling-off and a steady decline of environmental degradation.

With higher and appropriate technology, the environmental impact can be reduced to a minimum level of environmental degradation. Capturing POME emissions into biogas for energy generation, can significantly reduce the climate change impacts of palm oil production (Rahayu, 2015) and foster development in the most rural areas of Indonesia. There is a common agreement that the main driver for the growth of palm oil production in Indonesia over the reference period has been the demand for export purposes. Growing demand from countries like China and India, but also the EU-27 and Pakistan has driven business plans in Indonesia with a supply-response towards expanding the production. The ill-omened consequences of unplanned or poorly-regulated oil palm expansion, and thus the multiple social and environmental consequences of Land Use Changes will not be the focus of this paper but another fundamental contributor to environmental damages of the palm oil sector for which opportunities to diminish impacts are well proven and known exist will be discussed.

The theory behind environmental impact assessment developed by Ehrlich and Holdren can be used to run environmental estimation models of greenhouse gas emissions shown by Sorge, Neumann and Anne (2019) adopted Impact= Population $x$ Affluence $x$ Technology (IPAT) framework first proposed in the early 1970s as part of an ongoing debate on the driving forces of environmental change.

\section{RESEARCH METHODE}

This research will use a theory developed by Ehrlich and Holdren, concerning factors driving environmental degradation, summarized in the following equation: 


$$
\mathrm{I}=\mathrm{P} \times \mathrm{A} \times \mathrm{T}
$$

Where I is the level of environmental impact, $\mathrm{P}$ is the size of the population (in this case of the population that is primarily responsible for the demand of the commodity considered), $\mathrm{A}$ is the level of affluence to the specific resource per person (here importing country's GDP per capita is used as a proxy of unitary consumption), and $\mathrm{T}$ characterizes the technology used to produce products and services, or the social organization and culture which controlled how the technology may be used (here the production of POME per GDP at the province as a proxy of technology used). Based on this theory, we developed the predicted POME production equation as follows:

$$
\mathrm{POME}_{\mathrm{tp}}=\mathrm{aPOPI}_{\mathrm{t}}^{\mathrm{b}}\left(\mathrm{GDPI}^{\mathrm{P} O P I}\right)_{\mathrm{t}}^{\mathrm{c}}\left(\mathrm{POME}_{\mathrm{GDP}}\right)_{\mathrm{tp}}^{\mathrm{d}} \mathrm{e}_{\mathrm{tp}}
$$

Where POME is the production of POME in tons, POPI is the size of the population in the main importing country, GDPI/POPI is Gross Domestic Product per capita in main importing countries (based on constant value as of 2010), and POME/GDP is the production of POME per regional GDP of those five provinces in Indonesia, $t$ is the year of observation, $p$ is the province where POME measured and $e_{t}$ is a statistical error. To have the most versatile model of POME production the equation was turned into a logarithm equation, as follows:

$\log \left(\mathrm{POME}_{\mathrm{t}, \mathrm{p}}\right)=\mathrm{C}+\alpha 1 \log \left(\mathrm{POPI}_{\mathrm{t}}\right)+\alpha 2 \log (\mathrm{GDPI} / \mathrm{POPI})_{\mathrm{t}+} \alpha 3 \log (\mathrm{POME} / \mathrm{GDP})_{\mathrm{t}, \mathrm{p}}+\mathrm{e}_{\mathrm{tp}}$,

Where based on the theory, $\alpha 1, \alpha 2, \alpha 3>0$.

The above equation model was then calculated through the Eview Data Processing Software (Eview) to estimate specific parameters $(\alpha 1, \alpha 2$, and $\alpha 3)$. The validity of the model was tested with the Statistic Hausman Test. To find an appropriate model for the predicted POME production equation, the equation was subsequently tested with the Null Hypothesis (Ho): using the random-effect model; and Alternative Hypothesis, (H1): using the fixed-effect model.

The policy intervention to minimize the POME production was calculated based on (1) Scenario of 1 percent and 1.5 percent population increased, (2) Scenario of 6 percent and 8 percent GDP per capita increased and (3) Scenario of technology interventions that result in a 1 percent, 5 percent, and 10 percent reduction in POME per GDP.

\section{RESULT AND DISCUSSION}

The average POME production of the five provinces included in this study from 2010 to 2016 was increased, especially from 2014 to 2015, where the slope of POME production was higher than in other years. POME production in 2016 was about 2.4 million tons (Figure 3). 


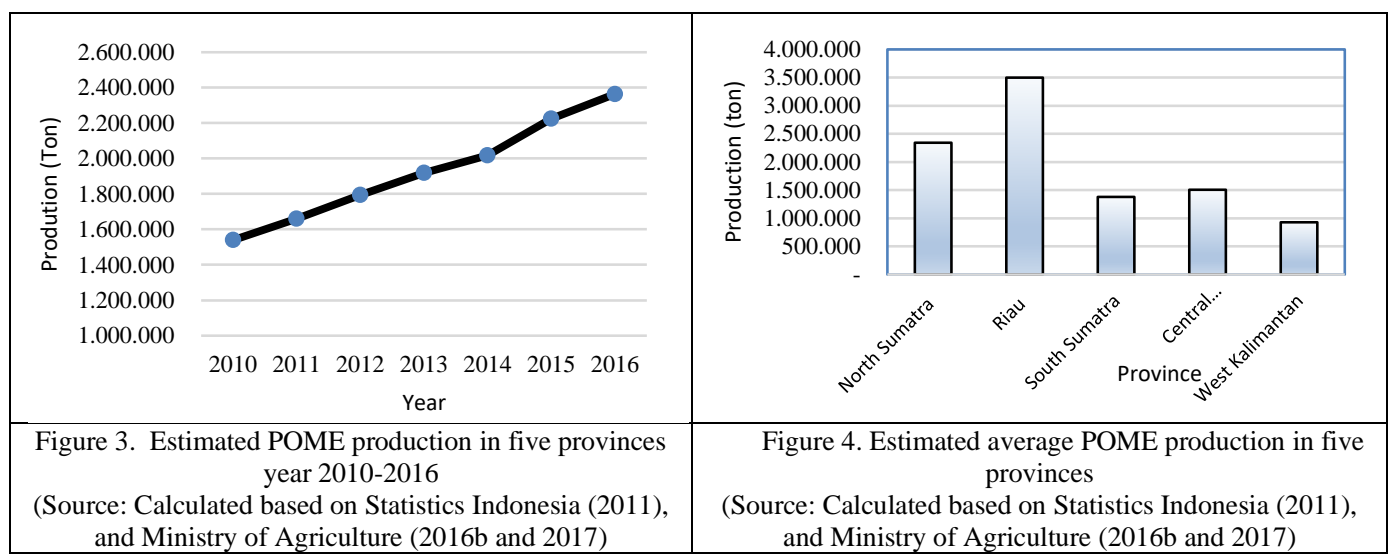

The average POME production per year in those five provinces, North Sumatra, Riau, South Sumatra, East Kalimantan, and West Kalimantan is shown in Figure 4. The highest average POME production per year in the period $2010-2016$ was in Riau followed by North Sumatra, with the production of about 3.5 million tons and 2.3 million tons respectively, followed by Central Kalimantan, South Sumatra, and West Kalimantan. The average production per year of all other provinces in Indonesia was less than these five main provinces.

Most of the Indonesian palm oil production is used for export, and about 23 percent of total exports go to India. The more demand for palm oil then the more palm oil and POME produced. Figure 5 shows the increasing trend of POME production per year due to the population increased (POPI) and GDP per capita (GDPI/POPI) in India, the year 2010-2016.

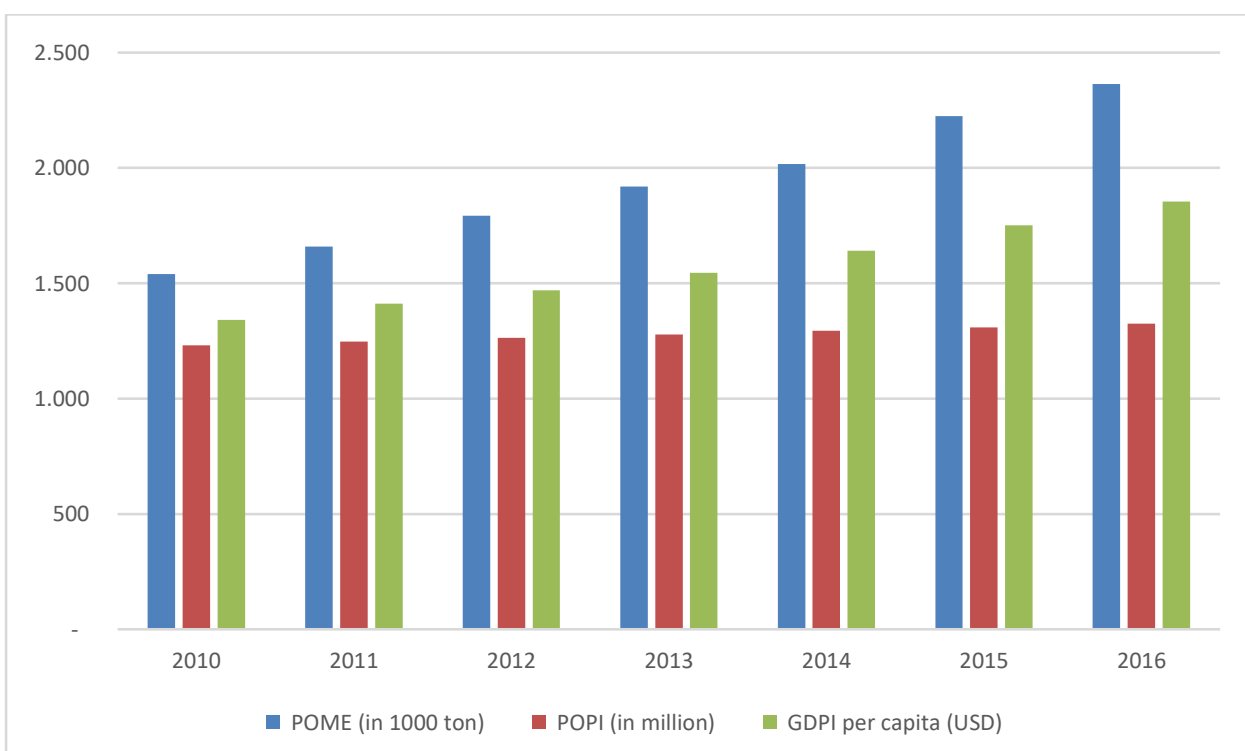

Figure 5. POME, POPI (Population Of Palm Oil Importing County, India) And GDPI (GDP per Capita Of Palm Oil-Importing Country, India) Year 2010-2016

(Source: Calculated based on FAO (2020) and United Nation (2020) Statistic Data)

The POME production was increased at an average annual rate of 7 percent between 2010 and 2016. Meanwhile, GDP per capita increased at an average annual rate of 6 
percent. The percentage of this POME, population of importing country (India) and GDP per capita of importing country (India) increased can be seen in Figure 6.

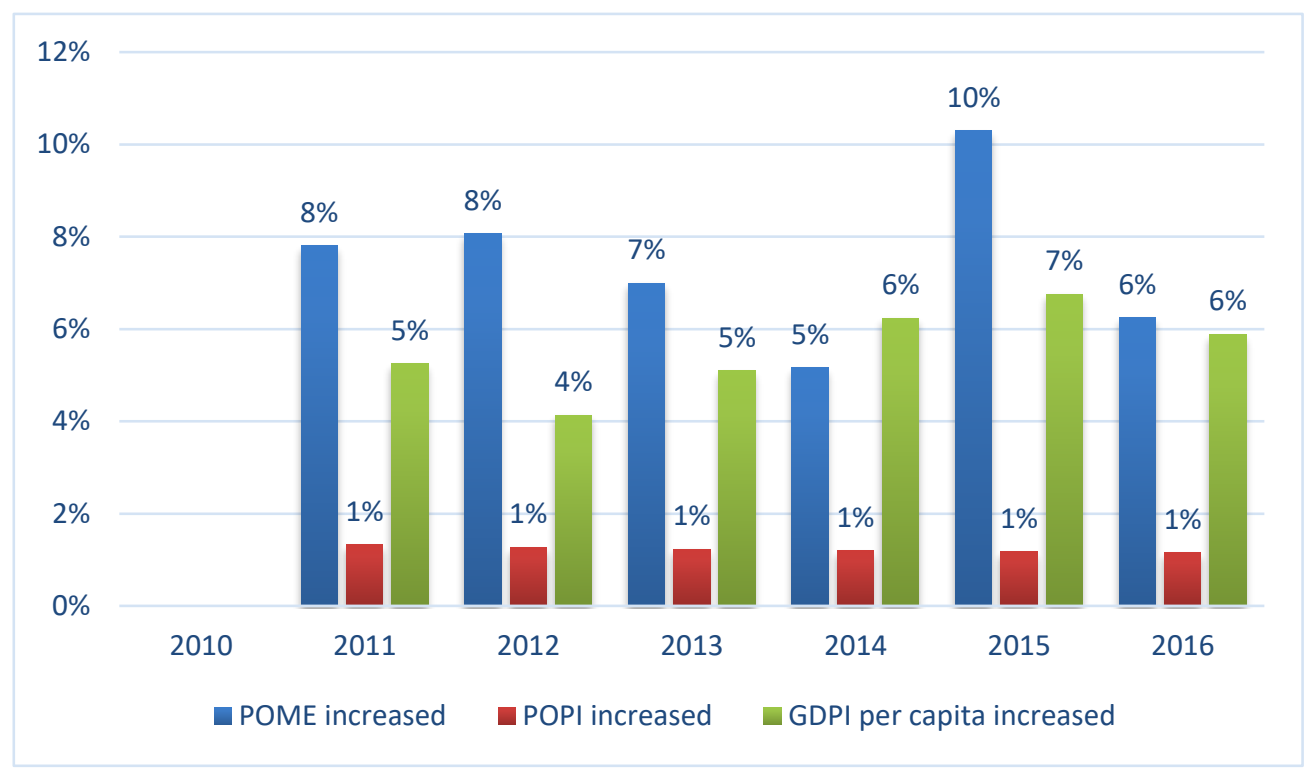

Figure 6. GDP Per Capita And POME Production Annually Increased

Based on the calculations processed by Eview it was found that statistical test probability $<5$ percent, (Prob F-Statistic $=0,000000$ ) shown an appropriate for this analysis. The predicted values of constant $C$, and parameters $\alpha 1, \alpha 2, \alpha 3$ of the population, GDP per capita and POME production per regional GDP of those five provinces in Indonesia, in the sequence were $-94.3,6.1,-0.4$, and 0.9 respectively with statistical test probability was $<5 \%$ for $\alpha 1$ and $\alpha 3$, and probability $>5 \%$ for $\alpha 2$, with the value $-0.4(\alpha 2<0)$. According to the theory $\alpha 1, \alpha 2, \alpha 3$ should be $>0$. So, we cannot accept $\alpha 2$.

The predicted equation model was then tested by the Hausman Test to find an appropriate model for the predicted POME production equation, as presented in Table 1, found that the probability cross-section random 1, so the random effect model was accepted.

Table 1. Correlated Random Effects - Hausman Test

Equation: Untitled

Test cross-section random effects

\begin{tabular}{lcr}
\hline \hline Test Summary & Chi-Sq. Statistic & Chi-Sq. d.f. Prob. \\
\hline \hline Cross-section random & 0.000000 & 31.0000 \\
\hline \hline * Cross-section test variance is invalid. Hausman statistic set to zero.
\end{tabular}

The following table (Table 2) reports the results of the random effect model and shows the predicted parameter for this POME production model. 
Table 2. Cross-Section Random Effects Test Equation

Cross-section random effects test equation:

Dependent Variable: LOG(POME)

Method: Panel Least Squares. Sample: 20102016

Periods included: 7

Cross-sections included: 5

Total panel (balanced) observations: 35

\begin{tabular}{|c|c|c|c|c|}
\hline Variable & Coefficient & Std. Error & t-Statistic & Prob. \\
\hline $\mathrm{C}$ & -94.31913 & 42.54772 & -2.216785 & 0.0352 \\
\hline LOG(POPI) & 6.150157 & 2.197196 & 2.799093 & 0.0093 \\
\hline LOG(GDPI/POPI) & -0.411898 & 0.491471 & -0.838091 & 0.4093 \\
\hline LOG(POME/GDP) & 0.930565 & 0.072830 & 12.77720 & 0.0000 \\
\hline \multicolumn{5}{|c|}{ Effects Specification } \\
\hline \multicolumn{5}{|c|}{ Cross-section fixed (dummy variables) } \\
\hline R-squared & 0.997069 & \multirow{7}{*}{\multicolumn{3}{|c|}{$\begin{array}{lr}\text { Mean dependent var } & 14.35463 \\
\text { S.D. dependent var } & 0.495039 \\
\text { Akaike info criterion } & -3.972509 \\
\text { Schwarz criterion } & -3.617001 \\
\text { Hannan-Quinn criteria. } & -3.849788 \\
\text { Durbin-Watson stat } & 0.281298\end{array}$}} \\
\hline Adjusted R-squared & 0.996309 & & & \\
\hline S.E. of regression & 0.030077 & & & \\
\hline Sum squared resid & 0.024424 & & & \\
\hline Log-likelihood & 77.51891 & & & \\
\hline F-statistic & 1311.984 & & & \\
\hline Prob(F-statistic) & 0.000000 & & & \\
\hline
\end{tabular}

Based on Table 2 of cross-section random effects test equation, the appropriate predicted model for POME production is:

$$
\mathrm{LOG}(\mathrm{POME})=-94.3+6.1 \mathrm{LOG}(\mathrm{POPI})-0.4 \mathrm{LOG}(\mathrm{GDP} / \mathrm{POPI})+0.9 \mathrm{LOG}(\mathrm{POME} / \mathrm{GDP})
$$

The model shows that the predicted model of POME production can explain the relationship between Population, GDP per capita of palm oil importing countries, POME production per GDP of Indonesia due to technology intervention, and POME production. The more population and POME per GDP of Indonesia then the more increase of POME production at the palm oil mills within six years of observation, from the year 2010 to 2016 . The value of $-0.4(\alpha 2<0)$ in this predicted model of POME production shows that this model cannot explain the relationship between GDP per capita of importing countries and POME production in Indonesia.

\section{Effect of Population of Palm Oil Importing Countries on POME Production}

With the predicted parameter of $\log (\mathrm{POPI})=6.1$, if the population of importing countries has 1 percent increased then the production of POME at five provinces will increase by 6.1 percent. 


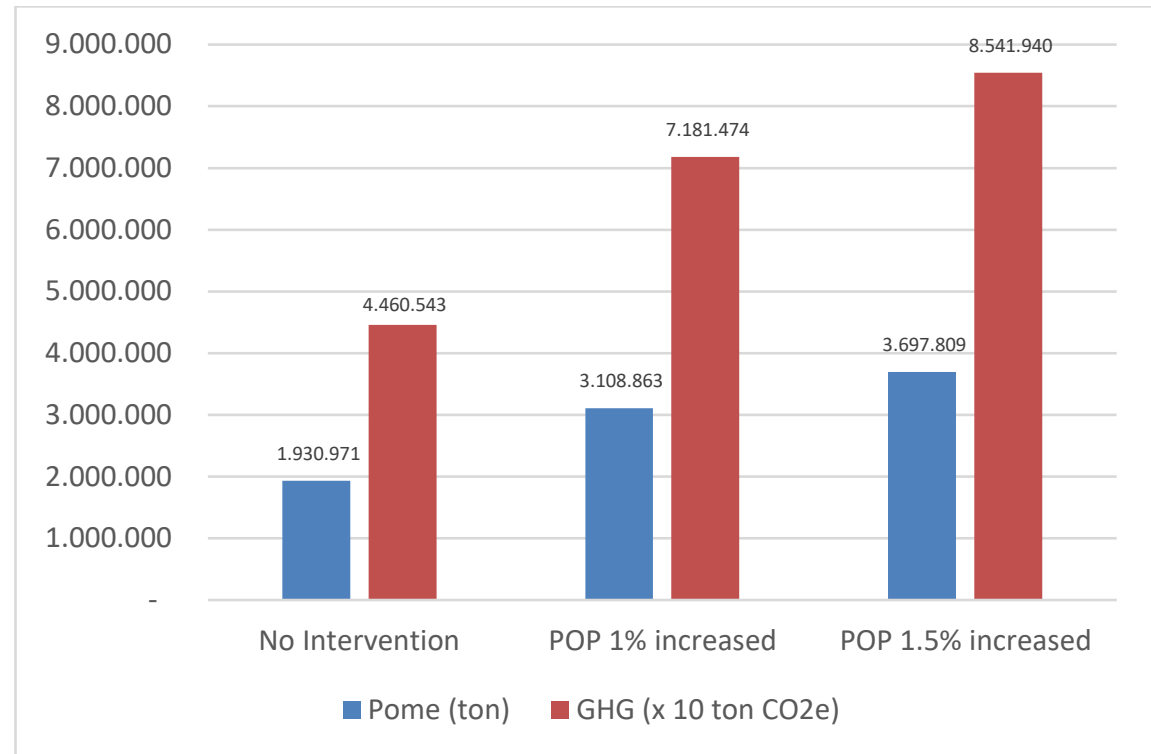

Figure 7. Scenario Effect Of Population On POME Production

Using the policy scenario intervention presented on Figure 7, with the scenario of 1 percent population increased may produce 3.1 million tons of POME production, and contribute to 71.8 million tons $\mathrm{CO}_{2 \mathrm{e}}$; and with the scenario, 1.5 percent of the population increased may produce 3.7 million tons of POME production, and contribute to 85.4 million tons $\mathrm{CO}_{2 \mathrm{e}}$. Higher population growth and growing consumption of food are driving to the more demand for palm oil. The more demand for palm oil for domestic and international consumption at the demand side will increase oil palm production on the supply side. Increasing the area of oil palm crops and palm oil production in Indonesia since 2010 (figure 1) is a positive response to world demand for palm oil in line with the growing population of importing countries of palm oil. Increasing world demand for palm oil is driving increased investment in Indonesia to set up more palm oil processing plants. The increasing number of palm oil mills, the more POME, as a result of the palm oil mill.

The Government of Indonesia has various regulations to manage the impacts generated by the industry, including the palm oil processing plant. The law of the Republic of Indonesia number 32 the year 2009 on environmental protection and management states the obligation of the processing industry to manage industrial waste in order not to produce waste which is harmful to the environment and disrupt the social life of the society. Obligations for the industry to have good plant waste management planning and activities. The Indonesian minister environment decree number 5 the year 2014 on wastewater quality standards mentions that concentration of the pollutants at the outflow of the wastewater treatment plant should always less than 25 percent of the inflow. The company under the Indonesian law number 40 the year 2007 on the incorporated company, has social and environmental responsibilities including environment protection, norms, and social culture responsibilities around the mills. Similar to Indonesia, Malaysia has an environment quality (prescribed premises) (crude palm oil (amendment) regulations year 1982 about the limit for the parameter of effluent to be discharged 
onto land. Providing environmental knowledge and education, including the impact of the environmental processing industry to consumers, will give the industry a boost to better manage POME waste.

\section{Effect of GDP per capita of Palm Oil Importing Countries on POME Production}

Based on the statistical calculation and analysis, it was found that the predicted parameter of $\log (\mathrm{GDPI})=-0.4$. According to the theory, the increase in GDP will produce higher POME production. So the parameter should be $>0$. In this case, the GDP per capita of palm oil importing countries cannot be used to predict POME production in Indonesia. In another word, it cannot explain the relationship between people's welfare and palm oil consumed.

\section{Effect of Technology on POME Production}

With a predicted parameter of $\log (\mathrm{POME} / \mathrm{GDP})=0.9$, if the production of POME per GDP increases 1 percent then the production of POME will increase of 0.9 percent.

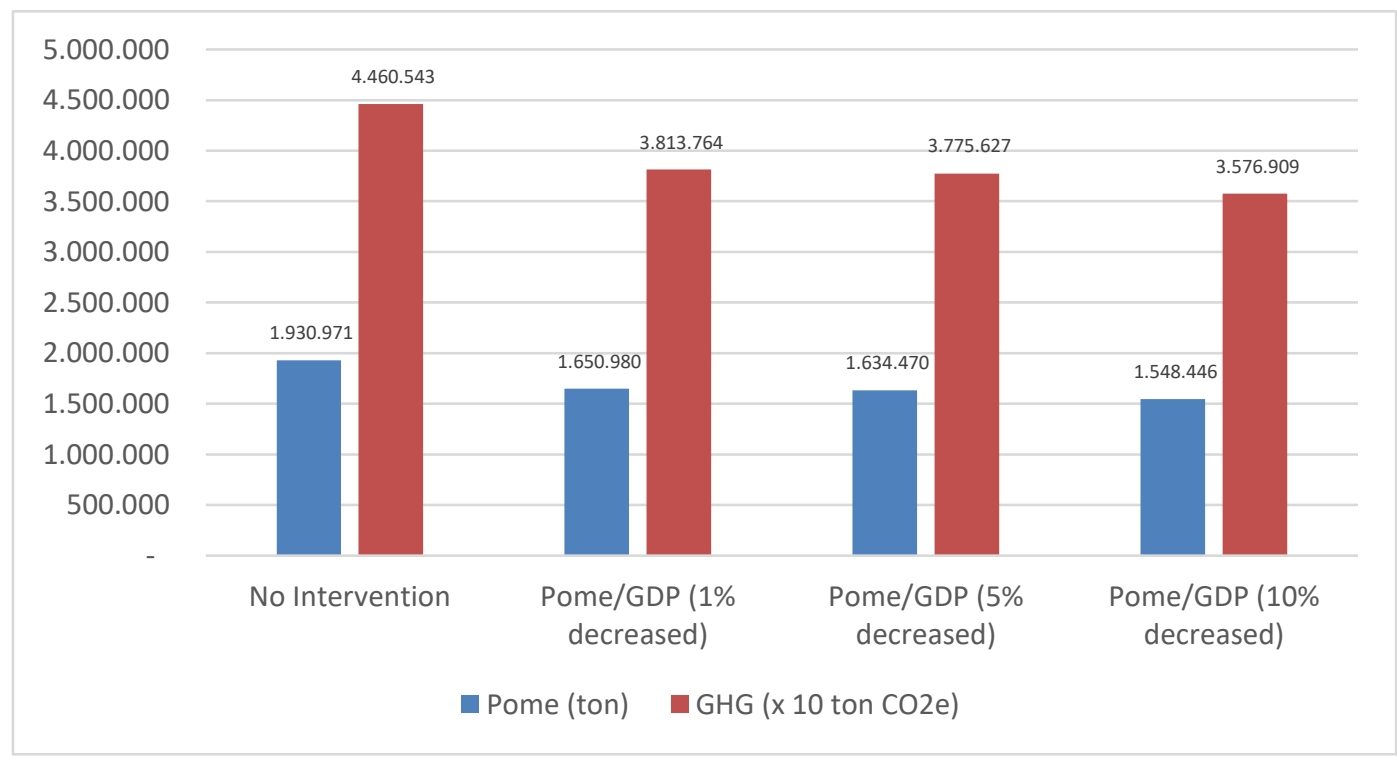

Figure 8. Scenario Effect Of Technology On The Production Of POME

With the scenario of the technology implementation, it will contribute to the decreasing of POME production per GDP. In Figure 8, where implement 1 percent higher technology could then only produce 1.65 million tons of POME production, contribute to 38.1 million tons $\mathrm{GHG} \mathrm{CO}_{2 \mathrm{e}}$. Implementing 5 percent higher technology could decrease into 1.63 million tons of POME production, contribute to decreasing GHG emission of 37.8 million tons $\mathrm{CO}_{2 \mathrm{e}}$, and with implement 10 percent higher technology could decrease into 1.55 million tons of POME production, decreased contribution to only 35.7 million tons $\mathrm{CO}_{2 \mathrm{e}}$.

The GDP at the observed provinces in the year 2010-2016 increased annually and gave good environmental support for the industry to invest more in the technology. The better technology applied to palm oil processing industries is very 
useful to support efficiency and less POME production. With the increase of GDP in Indonesia, it will provide good economic support for investment in better technology implementation to treat POME waste better. The wastewater treatment of POME in the mill, a source of methane emission could be decreased or removed in several ways (technologies). One of the technologies applied in Malaysia, a belt filter system to remove carbon from POME with solid separation in POME ponds, as cased study during January and February 2017, wherein this case study, 3.3 percent of the carbon in a daily amount of 27 tons (could potentially form 21 tons $\mathrm{CO}_{2 \mathrm{e}}$ ) can be removed, to reduce GHG POME emission of palm oil mill (Enström, 2017)

According to the Indonesia law number 3 the year 2014 on Industry, states that the minister of industry deciding policy, choices, provide, and utilization of industry technology to maintain sustainable environmental functions. The government policy in Thailand encourages companies to have certification for reducing emissions by at least 10 percent using minimal grid-purchased energy and leveraging high-efficiency technologies.

\section{Policy to reduce POME production}

POME produced by the mills will emit methane into the atmosphere, and through the application of methane capture technologies is capable of minimizing these emissions. The intervention of government through improved policies and oversight on the palm oil processing industry by implementing fiscal policy could encourage companies to adopt methane capture systems to support the country's zero waste program. An appropriate fiscal policy should encourage the palm oil industry to implement a sustainable manner of industries with low cost and effective technology. There is a need to do more research to see how current regulations better implemented, factories manage methane wastes in palm oil mills.

The policy of incentives and disincentives based on law number 46 of 2017 on environmental economic instruments should be able to encourage the industry to equip itself with better waste processing technology and better perform the waste treatment at the plant. This government policy should be supported by company willingness to practices at the field level, and certification of palm oil green products would be considered as green marketing policy to get more production sustainably. The implementation of those policies should be supported by technology readiness. It was recommended also to study more on the possibilities of transmission costs to incentivize methane capture systems that can be paid by buyers through the offset market of the GHG emission from POME through clean development mechanism practices at the mill level.

\section{E. CONCLUSIONS}

Palm oil is one of the promising agriculture commodities and has been proven contributing to government earning. Palm oil production in Indonesia is mainly for export. High demand for Indonesian palm oil comes from several countries, including India and China. The increase of the population in importing countries 
contributes to the more demand for palm oil, and contribute to a higher production of palm oil and POME.

Better economic growth will increase investment opportunities in Indonesia, including investment in the palm oil industry. The sustainable manner of palm oil industry encourages companies to implement a target of zero waste management and less contribution to GHG emission. Technology intervention can be used to minimized POME production. Several technologies have been tried, including in using palm oil liquid waste for electricity, etc.

Government policies on the green economy have been initiated in Indonesia, including on palm oil processing industries. The environment economic instrument such as fiscal policy might encourage industry to better POME methane capture system and utilization by appropriate technology intervention. The incentive for a better methane capture system could be also potentially used to support in carbon offset of clean development mechanism (CDM) at palm oil mills, to fund research on better technology. 


\section{REFERENCE}

Anon. (2017). What about Indonesia's Crude Palm Oil (CPO) Export in 2017? In Https://Www.Indonesia-Investments.Com/Id/News/TodaysHeadlines/What-About-Indonesia-S-Crude-Palm-Oil-Cpo-Export-in2017/Item7694. $\quad$ https://www.indonesia-investments.com/news/todaysheadlines/what-about-indonesia-s-crude-palm-oil-cpo-export-in2017/item7694?

Dornbusch, R., Fischer, S., \& Startz, R. (2011). Macroeconomics (eleventh). New York, NY 10020: McGraw-Hill

Enström, A. (2017). GHG reduction with solid separation in POME ponds

Food and Agriculture Organization of the United Nations (FAO). (2014). Pilot Testing of GBEP Sustainability Indicators for Bioenergy in Indonesia. Retrieved from http://www.fao.org/3/a-i4059e/index.html

Food and Agriculture Organization of the United Nations (FAO). (2020). FAOSTAT_data_8-22-2020. http://www.fao.org/faostat/en/\#data/OA

Jones, C. I., \& Klenow, P. J. (2016). Beyond GDP? Welfare across countries and time. American Economic Review, 106(9), 2426-2457. https://doi.org/10.1257/aer.20110236

Kuala Lumpur Kepong Berhad. (n.d.). Sustainability Mission Statement. Retrieved from www.klk.com.my

Miller, A. (1999). Environmental Problem Solving - Psychosocial Barriers to Adaptive Changes. Springer Series on Environmental Management. (D. E. Alexander, Ed.). New York: Springer Science + Business Media, LLC. https://doi.org/10.1007/978-1-4612-1440-3

Ministry of Agriculture. (2016). Agricultural Statistics 2016. Ministry of Agriculture Republic of Indonesia. http://epublikasi.setjen.pertanian.go.id/arsip-perstatistikan/407-statistikpertanian-2016

Ministry of Agriculture. (2016). Tree Crop Estate Statistics of Indonesia 20152017. Ministry of Agriculture Republic of Indonesia. https://docplayer.info/65610827-Statistik-perkebunan-indonesia-tree-cropestate-statistics-of-indonesia.html

Ministry of Agriculture Republic of Indonesia. http://epublikasi.setjen.pertanian.go.id/download/file/390-statistik-pertanian2017

Nur, S. M. (2014). Karakteristik Kelapa Sawit sebagai Bahan Baku Bioenergi. PT. Insan Fajar Mandri Nusantara. https://www.academia.edu/5968291/Karakteristik_Kelapa_Sawit_sebagai_B ahan_Baku_Bioenergi 
Ohimain, E., \& Izah, S. (2014). Possible Contributions of Palm Oil Mill Effluents to Greenhouse Gas Emissions in Nigeria. British Journal of Applied Science \& Technology, 4(33), 4705-4720. https://doi.org/10.9734/bjast/2014/10698

Panayotou, T. (2003). Economic Growth and the Environment, Economic Survey $\begin{array}{lll}\text { of } & \text { Europe } & \end{array}$ https://www.unece.org/fileadmin/DAM/ead/pub/032/032_c2.pdf

Pangsapa, P. (2014). Environmental justice and civil society from: Routledge Handbook of Environment and Society in Asia Routledge (No.2). Routledge Informa Ltd. https://www.routledgehandbooks.com/doi/10.4324/9781315774862.ch3

Rahayu, A. S., Karsiwulan, D., Yuwono, H., Trisnawati, I., Mulyasari, S., Rahardjo, S., Hokermin, S., \& Paramita, V. (2015). Handbook POME-to-Biogas Project Development in Indonesia (B. Castermans, H. Yuwono, R. Hardison, \& V. Paramita (Eds.)). Winrock International. https://www.winrock.org/wpcontent/uploads/2016/05/CIRCLE-Handbook-2nd-Edition-EN-25-Aug2015-MASTER-rev02-final-new02-edited.pdf

Sorgea, L., \& Neumann, A. (2019). www.econstor.eu (DIW Discussion Papers, No. 1812; ISSN Electronic Edition 1619-4535). https://www.econstor.eu/bitstream/10419/201393/1/1670260879.pdf

Statistics Indonesia. (2012). Indonesian Oil Palm Statistics 2011. BPS - Statistics Indonesia.

Tietenberg, T., \& Lewis, L. (2012). Environmental \& Natural Resource Economics (9th ed.). Pearson Education, Inc.

United Nation. (2020). Gross Domestic Product (GDP). https://unstats.un.org/unsd/snaama/CountryProfile?ccode $=356$

Varga, S. (2017). Essential Palm Oil Statistics 2017. http://www.palmoilanalytics.com/files/epos-final-59.pdf 